\title{
PHAGOCYTOSIS AND CLOTTING IN THE PERIVISCERAL FLUID OF ARBACIA.
}

JAMES ERNEST KINDRED,

Biological Department of Western Reserve University, Cleveland, Ohio.

The perivisceral fluid of the Echinoidea contains certain formed cellular elements which have been observed and described by Valentin ('42), Williams ('56), Hoffman ('72), Prouho ('86), Geddes ('80), Cuénot ('9I) and Théel ('96). For most of our knowledge of these cellular elements we are indebted to Geddes and Cuénot. Goodrich ('I9) in his discussion of the leucocytes of the invertebrates is the most recent contributor.

Cuénot observed that these formed elements were found not only in the perivisceral cavity, but also in the lumina of the ambulacral system; in the lacunæ of the intestinal walls and in all other organs of the body. He further observed that they were not all of one type, but could be divided into two distinct series, each of which series could be further subdivided. The first series of cells he called "vibratile globules," minute cells 6-9 micra in diameter having a head and vibratile tail. The head is mostly nucleus enclosed in a thin sheath of cytoplasm. According to Cuenot the function of this type of cell is to keep the fluid contents of the perivisceral cavity in motion.

The second series of cells were called "amibocytes" and were subdivided into several different types. The first type, from which Cuénot assumed the other types to be derived, was found abundantly in the lymph-glands. The cells of this type were characterized by a homogeneous cytoplasm, long and numerous pseudopodia, and a relatively large nucleus within which was a distinct nucleolus. Sometimes the amibocytes of this type enclosed yellow or brown refractile granules. According to Geddes these were the most numerous of the corpuscles and all of the investigators have agreed that these cells are the chief agents in the formation of the blood clot. Because of this activity 
Dekhuyzen ('or) named them "thrombocytes" and compared them to the blood platelets of the vertebrates. Cuénot, Geddes and Dekhuyzen believed that when a clot was formed, these cells fused with each other to form larger true plasmodial masses, the cells of such a mass losing their identity. In order to check this assumption, Geddes introduced colored granules into the perivisceral fluid and observed that these colored granules were to be found in the large multinucleate masses which were formed by the fusion of the amibocytes. Michel ('88) and Goodrich ('I9) claim that these cells do not form true plasmodial masses, but do form aggregate plasmodia in which the cells retain their identity and are in contact by their ectoplasmic surfaces alone. Goodrich states further that these cells, instead of having a number of delicate pseudopodia, are under normal conditions provided with numerous flap-like membranous processes similar to the undulating membranes of the Protozoa. These membranous flaps when viewed in optical section have the appearance of delicate pseudopodia. The membranous flaps are constantly changing and when a drop of the perivisceral fluid is taken out of the cavity and spread out on a slide, these cells clump together if approximate to each other; if isolated, the membranes shrink as the fluid evaporates leaving long, filamentous strands of ectoplasm.

The other types of amibocytes are larger than those just described and contain colored or colorless globules. They also have a relatively smaller nucleus and form blunt pseudopodia when moving in the perivisceral fluid. Various functions have been ascribed to these larger amibocytes. The red, green and yellow material appearing in these amibocytes was said by Cuénot to be stored fat; by McMunn to be a respiratory pigment which he called by the non-committal name of echinochrome; and by Ribaucourt this colored material was thought to be excretory matter which was to be carried out of the body through the ambulacral system by these amibocytes. They were all agreed that these amibocytes were derived from the first type of amibocyte by the inclusion of this material or by its precipitation after absorption. Since these nutritional or nephritic 
cells take but a passive part in the formation of a clot and none at all in phagocytosis, they will not be considered further. The name leucocyte which Goodrich applied to the first type of amibocyte will be used here to designate the type of amibocyte active in the process of phagocytosis and clotting.

The leucocytes of Arbacia have the same general appearance as those figured by Goodrich for Asterias, but the membranes of the leucocytes of Arbacia seem to be larger in comparison to the amount of endoplasm than do those of Asterias. As the leucocyte moves about in the plasma medium the membranes are constantly changing (Fig. I, $a, b, c$ ). In the living condition,

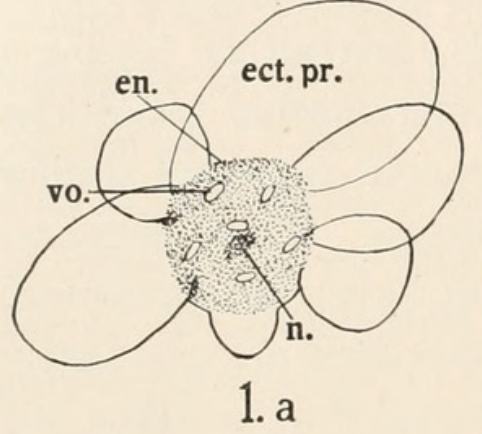

1. a
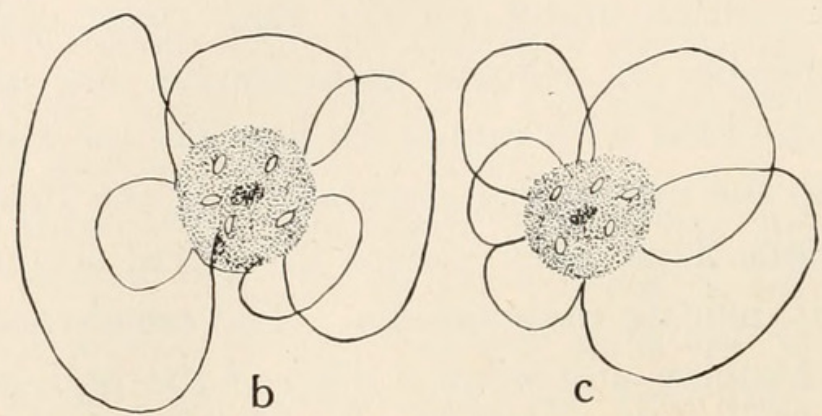

FIG. I, $a, b, c$. Leucocyte of Arbacia moving freely in plasma medium, drawn at five-minute intervals. Semi-diagrammatic. $\times$ I,5oo. ect. pr., ectoplasmic process; en., endoplasm; $n$., nucleus; vo., vacuoles.

the cytoplasm of the leucocyte appears finely granulate and contains five or six hyaline vacuoles. The nucleus is scarcely discernible in the living cell, but when treated with Flemming's or Herman's fluid it appears as a large ovoid body with a very distinct membrane. The chromatin granules are very prominent in the nucleus of those cells stained with Haidenhain's

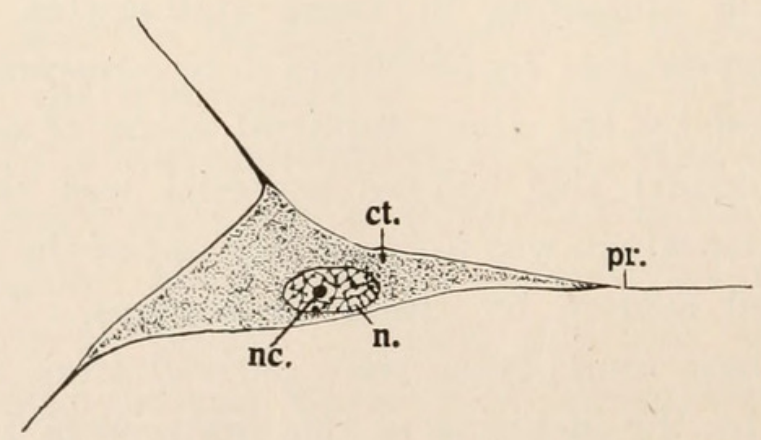

FIG. 2. Leucocyte of Arbacia from clot. Semi-diagrammatic. $\times 2,500$. ct., cytoplasm; $n$., nucleus; $n c .$, nucleolus; $p r$. , ectoplasmic process. 
hæmatoxylin. A large nucleolus is also present. When fixed with Schaudinn's fluid and stained with Haidenhain's hæmatoxylin, the cytoplasm appears reticulate (Fig. 2).

\section{Phagocytosis.}

Carmine and india ink suspensions in sea-water were used in order to determine the extent to which the leucocytes took part in the inclusion of foreign particles from the perivisceral fluid. One cubic centimeter of sea-watèr suspension of finely powdered carmine was introduced into the perivisceral fluid through a perforation in the peristomial membrane. The individual so treated was put back into the aquarium and at the end of thirty minutes a drop of the perivisceral fluid was examined. Although a large number of carmine grains were yet free in the plasma, it was observed that all of the leucocytes had taken up one or more particles. At the end of an hour another examination was made of the perivisceral fluid and at this time the plasma was comparatively free from carmine particles and the leucocytes were heavily loaded with them. The ingestion of several of these particles by the leucocyte was observed. This individual was kept in the aquarium for two weeks during which time the perivisceral fluid was examined at intervals. At the end of two weeks some leucocytes containing carmine particles were still present in the perivisceral fluid. This fact indicates a period of longevity on the part of these cells, but the fate of the large number which performed the function of phagocytes is still in doubt. Ribaucourt suggested that after they had become loaded with waste material from the perivisceral fluid they made their way into the ambulacral system by diapedesis and thence

- passed out through the madrepore. Since, however, no currents have been observed nor any cells observed leaving the madrepore, this assumption is unconvincing. The problem of excretion and with it the fate of the old phagocytes has yet to be solved.

The results obtained by the injection of I c.c. of india inksea-water suspension were the same as those obtained with the carmine suspension. And further in the study of the clot, it was observed that the ingestion of particles by the leucocytes does not inhibit their activity in the formation of the clot. 
In both of these experiments the amibocytes other than phagocytes did not act as phagocytes. This may be due to the fact that, if they are, as assumed, derived from leucocytes in the first place by the inclusion of reserve food material or absorption of nitrogenous waste, the material so added inhibits any phagocytic activity.

\section{Reactions to Vital Stains.}

No success was met with in the attempt to stain the leucocytes by the injection of weak intravitam stains. Aqueous solutions of methyl blue, methyl green, Janus green, and trypan blue were introduced into the perivisceral cavity, but no effect on the formed elements was noted.) A I:500 methyl blue-sodium chloride solution had no effect upon the leucocytes, but faintly stained the globules in the red amibocytes ("globules amœboide brun d'acajou" of Erdle).

One c.c. of .or per cent. neutral red in sea-water was injected into the perivisceral fluid of several individuals and after twentyfour hours all of the leucocytes in several drops of the perivisceral fluid examined contained yellow globules. This indicated that the hyaline globules apparent in the leucocyte under normal conditions have an alkaline content.

\section{iII. Clotting.}

A drop of the perivisceral fluid of Arbacia, freshly drawn, when placed on a cover slip immediately shows signs of agglutination. The large pigmented and colorless amibocytes appear in long strings held together by the clumping of the leucocytes, although in many cases the leucocytes had not lost their membranous processes. A drop of the perivisceral fluid was placed on a glass slide and observed continually for two hours. Sketches of the changes which were taking place in the shape of the cells in a restricted area were made at intervals of thirty minutes in order to show the rôle played by the leucocytes in the formation of the clot. When first observed there were four leucocytes in the field, each possessing the typical membranous projections (Fig. 3). As the fluid evaporated during the course of an hour these leucocytes came into contact with the slide. 
Whereupon the membranous processes of the ectoplasm began to shrink and the leucocyte to elongate (Fig. 4). Several red, yellow and colorless amibocytes which were in the vicinity

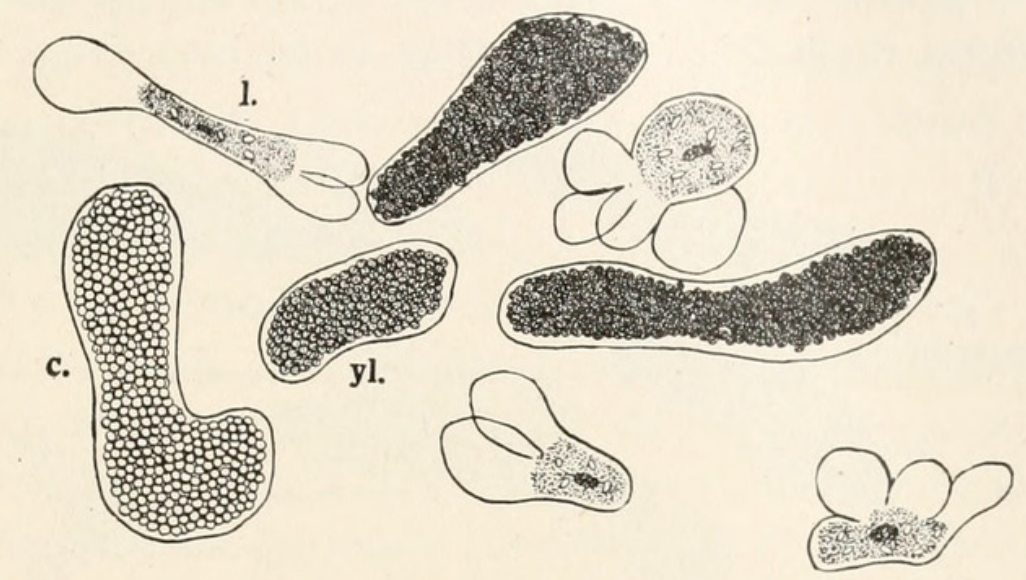

FIG. 3. Group of cells in perivisceral fluid on slide. Semi-diagrammatic. $\times \mathrm{I}, 000$.

adhered to the margins of the leucocytes as if the latter were secreting a sticky substance. At the end of one and a half hours the leucocytes had become extremely elongate and the membranous projections had entirely disappeared (Fig. 5). The filamentous projections left from the membranes extended across the field and came into contact with those of the neighboring leucocytes so that a meshwork was established to which the larger pigmented and colorless amibocytes adhered.

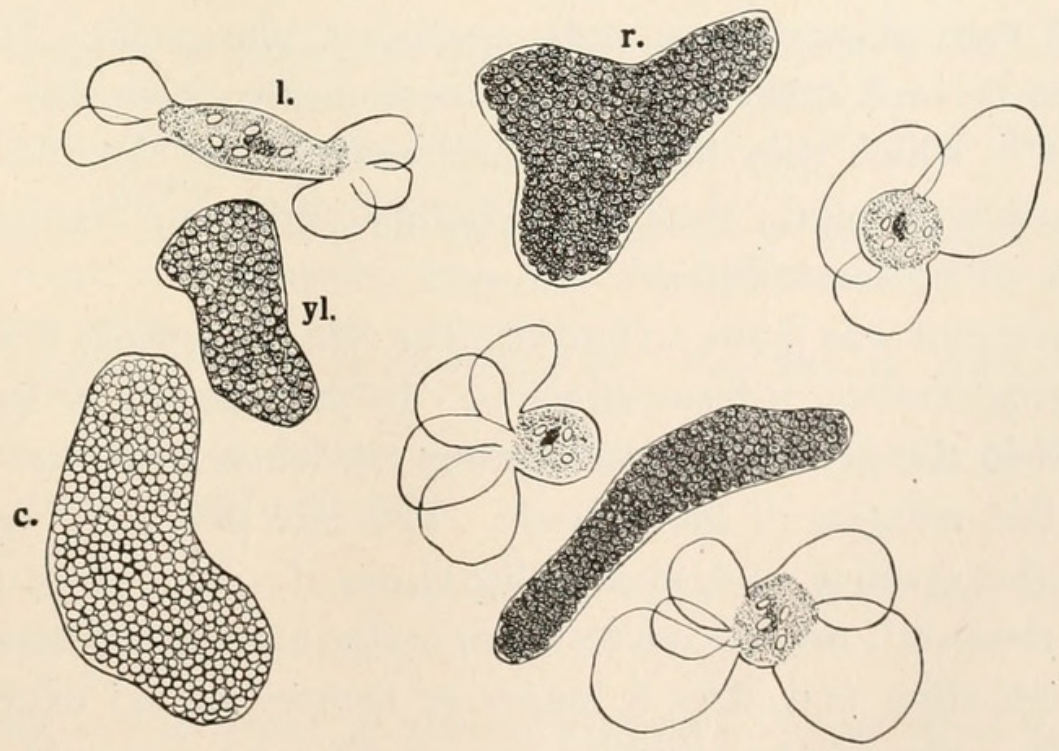

FIG. 4. Same group of cells as in Fig. 3, drawn 30 minutes later to illustrate begin ning of clot formation. Semi-diagrammatic. $X_{\mathrm{I}, \text { ooo. }}$ 
The activity of the leucocyte was then observed in a hanging drop, but typical clot formation did not occur except where the leucocytes came in contact with the glass. If the leucocytes in this drop were isolated from each other they retained their membranous projections, but if they came into contact with

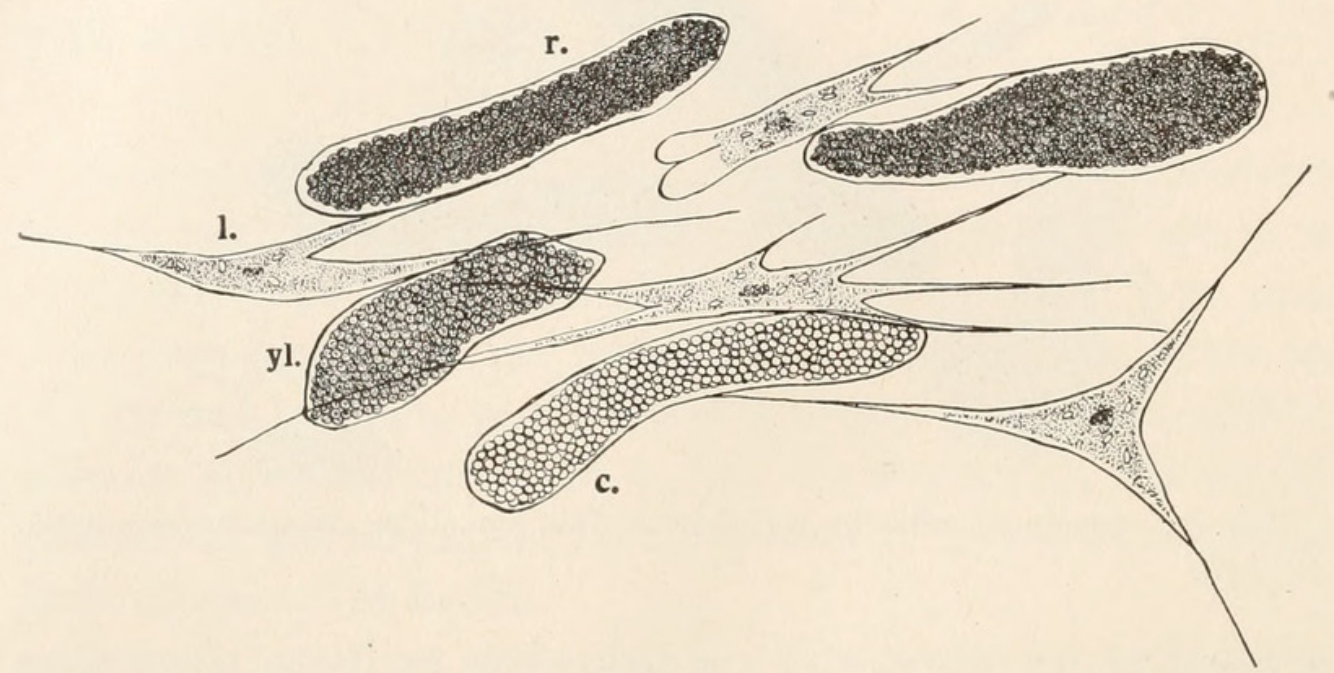

FIG. 5. Same group of cells as in Figs. 3 and 4. Clot fully formed. Drawn 30 minutes later than Fig. 4. Semi-diagrammatic. $\times_{\mathrm{I}, 000 .}$., amibocytes with colorless globules; $l$., leucocyte; $r$., amibocyte with red globules; $y l$., amibocyte with yellow globules.

each other they tended to stick together and form a mass to which the other amibocytes adhered. A meshwork such as observed under the conditions of evaporation did not appear. I was unable however to observe whether or not the leucocytes formed true plasmodia or only aggregate plasmodia. If their reaction to each other in forming these masses is similar to the manner in which they form the meshwork of the clot then they must certainly retain their individuality and come into contact without cytoplasmic fusion.

An attempt was made to find out the rôle the leucocyte played in the regeneration of resected parts. In the case of a perforation or a slit in the peristomial membrane, the leucocytes form a clot along the margins of the wound. This clot gradually extends across the opening and eventually closes it. If a piece of the test is removed, the leucocytes form a clot around the margin of the perforation and after a longer or shorter period depending upon the size of the piece cut out, this clot closes it. The 
further history of the relation of the clot to the tissues originally occupying the resected area will be followed later.

\section{SUMMARY.}

I. Phagocytosis in the perivisceral fluid of Arbacia is carried on by the leucocytes alone. These cells possess membranous processes similar to those of the leucocytes of Asterias and are the smallest and most numerous of the amibocytes. As phagocytes the leucocytes have a long period of activity.

2. The leucocytes tend to agglutinate even in freshly drawn perivisceral fluid. In a drop of perivisceral fluid on a plane surface, the leucocytes lose their characteristic membranous processes upon contact with the surface and become elongate. Long filamentous processes are produced by the shrinkage of the membranous processes. These filamientous processes adhere to those of neighboring leucocytes forming a delicate mesh to which the pigmented and colorless amibocytes adhere.

3. The leucocytes show an alkaline reaction when treated with neutral red in sea-water, but are not affected by weak solutions of intravitam stains introduced into the perivisceral cavity.

4. If a piece of the peristomial membrane or the test is resected, the leucocytes form a clot which closes the wound.

\section{Cuénot, L.}

\section{BIBLIOGRAPHY.}

'89 Etudes sur le sang, son role et sa formation dans la serie animale. Partie 2. Invertebrés. Note preliminaire. Arch. Zool. exper., Ser. 2, Tome 7: I-9.

'9r Etudes Morphologiques sur les Echinodermes. 8 Taf. Arch, Biol., Tome I I : 303-680.

'9r Etudes sur le sang et les glandes lymphatiques dans la serie animale. Partie 2. Invertebrés. Arch. Zool., Ser. 2, Tome 9: 613-64I.

Dekhuyzen, M. C.

'or Ueber die Trombocyten (Blutplättchen). Anat. Anz., I9: 529-540.

Geddes, P.

'8o Observations sur le fluide perivisceral des oursins. Arch. de Zool. exp. et gener., Tome 8: 483-496.

Goodrich, E. S.

'I9 Pseudopodia of the Leucocytes of Invertebrates. Quart. Jour. Micr. Sci., Vol. 64: I9-27.

Griffiths, A. B.

'92 Sur l'echinochrome: un pigment respiratoire. Compt. Rend. Acad. Sc. Paris, Tome II 5: 419-420. 
Kollmann, M.

'o8 Recherches sur les Leucocytes. Ann. Sc. Nat. Zool., Ser. 9, Tome 8. List, Th.

'97 Ueber die Entwickelungen von Proteinkrystalloiden in den Kernen der Wanderzellen bei Echiniden. Anat. Anz., I4: I85-I9I.

Michel, A.

'88 Sur la pretendue fusion des cellules lymphatiqués en plasmodes. Compt. Rend. Acad. Sci. Paris, Tome 106.

McMunn, C. A.

'85 On the Chromatology of the Blood of Some Invertebrates. Quart. Jour. Micr. Sci., Vol. 25: 469-490.

Prouho, H.

'86 Sur le Systeme vasculaire des Echinides. Compt. Rend. Acad. Sci. Paris, Tome I03: 560-563.

Schäfer, E. A.

'83 On the Perivisceral Fluid of the Sea Urchin (Echinus). Proc. Roy. Soc. London, Vol. 34: 370-37I.

Théel, H.

'96 Remarks on the Activity of Amœboid Cells in'the Echinoderms. Festsch. Lilljeborg Upsala. pp. 47-58.

Valentin, G.

'42 L'Anatomie du genre Echinus. In L. Agassiz's Description des Echinodermes vivans et fossiles.

\section{Williams, Thos.}

'56 On the Mechanism of Respiration in the Family of Echinidæ. Rep. Brit. Assoc. Adv. Sci., 26th Meeting. 


\section{$2 \mathrm{BHL}$ Biodiversity Heritage Library}

Kindred, James Ernest. 1921. "PHAGOCYTOSIS AND CLOTTING IN THE PERIVISCERAL FLUID OF ARBACIA." The Biological bulletin 41, 144-152. https://doi.org/10.2307/1536745.

View This Item Online: https://www.biodiversitylibrary.org/item/15842

DOI: https://doi.org/10.2307/1536745

Permalink: https://www.biodiversitylibrary.org/partpdf/4018

\section{Holding Institution}

MBLWHOI Library

\section{Sponsored by}

MBLWHOI Library

\section{Copyright \& Reuse}

Copyright Status: NOT_IN_COPYRIGHT

This document was created from content at the Biodiversity Heritage Library, the world's largest open access digital library for biodiversity literature and archives. Visit BHL at https://www.biodiversitylibrary.org. 